\title{
BANGUNAN PENGOLAHAN AIR SEBAGAI SOLUSI KETERBATASAN AIR BERSIH DI MUARA BARU
}

\author{
Johnson Wijaya ${ }^{1)}$, Martin Halim²) \\ 1)Program Studi S1 Arsitektur, Fakultas Teknik, Universitas Tarumanagara, Johnsonwijaya@yahoo.com \\ 2)Program Studi S1 Arsitektur, Fakultas Teknik, Universitas Tarumanagara, martinhalim90@gmail.com
}

Masuk: 03-07-2021, revisi: 13-08-2021, diterima untuk diterbitkan: 23-10-2021

\begin{abstract}
Abstrak
Daerah Muara Baru dikenal sebagai daerah yang kekurangan air bersih. Penduduk setempat mencoba beradaptasi dan memenuhi kebutuhan air bersihnya dengan membeli air pikulan. Proyek Pengolahan Air RE.TREAT merupakan proyek pengolahan air hujan dan air waduk yang dimanfaatkan kembali menjadi suplai air bersih di Muara Baru. Berdasarkan definisinya, Proyek Pengolahan Air RE.TREAT memiliki makna sebagai tempat memproses dan memelihara air untuk suplai air bersih yang dipakai kembali dan rekreasi untuk mencari ketenangan batin. Proses penelitian diawali dari langkah pemetaan daerah terdampak krisis air bersih. Kemudian site dengan potensi terbaik dianalisis lingkungan sekitarnya melalui prinsip landscape urbanism untuk menghasilkan pedoman mendesain. Pedoman mendesain kemudian dituangkan melalui studi gubahan massa dalam menciptakan bangunan Pengolahan Air RE.TREAT. Dengan RE.TREAT sebagai hasil arsitektur pengolahan air dan fungsi penunjang rekreasi setempat, maka penduduk Muara Baru akan memiliki sumber air bersih baru dengan harga yang lebih terjangkau dan ruang terbuka publik untuk melepas penat di tengah area pelabuhan dan perkampungan yang hiruk pikuk.
\end{abstract}

Kata Kunci: Keterbatasan air bersih; Pengolahan air; Muara Baru

\begin{abstract}
Muara Baru region is well known as the area with clean water scarcity. The locals tried to adapt by fulfilling the daily needs of water with purchasing water on wheels. RE.TREAT Water Treatment Project involves rainwater harvesting and dam water treatment and process them as clean water supply in Muara Baru. By definition, RE.TREAT Water Treatment Project would be defined as a place to process and treat water as a clean water supply to the neighbourhood and provides recreational space to self sooth. The research began with mapping the affected area of the clean water scarcity. Thus the best possible location was chosen and analyzed with the principles of landscape urbanism to create the base design guideline. Being the result of the concept, the base design guideline is applied in the massing study and thus created the RE.TREAT Water Treatment Project. With the purpose of water treatment and supporting recreational functions, the residents of Muara Baru will have a steady clean water source with a more affordable price and a public space to get away from the crowd and daily routine.
\end{abstract}

Keywords : clean water scarcity; water treatment; Muara Baru

\section{PENDAHULUAN}

\section{Keterbatasan air bersih di Muara Baru, Jakarta Utara}

Masalah keterbatasan air sudah tidak asing lagi bagi warga RW 17 yaitu di kawasan Muara Baru, Jakarta Utara. Tidak sedikit warga yang kurang puas dengan air yang keluar dengan memasang pompa milik Perusahaan Air Minum (PAM), seperti dikutip dari salah satu narasumber Yuyun saat ditemui di kediamannya, "Bukan kekurangan air, dari dulu juga udah kekurangan air. Saya masang PAM bertahan 6 bulan, yang keluar cuma lumpur. Saya mau ngisi (bak) air nggak ada" (Jakarta Utara, Rabu 24/7/2019)(Detiknews, 2019). Warga pun memutuskan untuk membeli air bersih dalam bentuk jeriken untuk memenuhi kebutuhan sehari-hari. 
Tak sedikit masyarakat yang merasa keberatan dengan biaya yang dikeluarkan untuk membeli air bersih jeriken tersebut. "(Biar dapat air) ya beli pikulan. Sehari bisa beli 4 pikul (jeriken), satu pikul Rp 5.000, dikaliin tuh. (Bahkan) sehari bisa lebih dari 4 pikul. Sehari (pengeluaran) bisa Rp 50.000 sampai Rp 40.000 buat beli air aja itu," ucap Yuyun(Detiknews, 2019). Anies Baswedan pun menambahkan bahwa warga mengeluarkan sampai Rp 600.000,- per bulan untuk membeli air eceran tersebut sedangkan warga yang berlangganan air pipa hanya mengeluarkan Rp 120.000,- sampai dengan Rp 150.000,- (Prabowo, H, 2019).

Masalah air bersih ini pun diklaim oleh Kepala UPT Pusat Data dan Informasi Kebencanaan BPBD DKI, Muhammad Ridwan, merupakan akibat dari faktor geografis yang berdekatan dengan laut sehingga air yang dihasilkan sumur menyusut dan ditambah faktor musim kemarau yang menyebabkan kebutuhan air bersih semakin meningkat(Prabowo, H, 2019).

\section{Rumusan Permasalahan}

- Apa penyebab keterbatasan air bersih di Muara Baru?

- Bagaimana solusi untuk mengatasi masalah keterbatasan air bersih di Muara Baru?

\section{Tujuan}

Menciptakan ruang yang menjawab permasalahan keterbatasan air bersih di Muara Baru dengan hasil karya arsitektur berupa usulan desain proyek yang meliputi fungsi utilitas pengolahan air dari sumber air setempat dengan dampak kebaikan bagi penduduk Muara Baru.

\section{KAJIAN LITERATUR}

\section{Beyond Ecology}

Berdasarkan Kamus Besar Bahasa Indonesia, "Beyond Ecology" atau diterjemahkan menjadi "Melampaui Ekologi" dapat diartikan menjadi Melampaui, dari kata dasar lampau, yang berarti melalui, melewati, melebihi, melintasi, mengatasi dan Ekologi, yang berarti Ilmu tentang hubungan timbal balik antara makhluk hidup dan (kondisi) alam sekitarnya (lingkungannya). Berdasarkan kesatuan makna tersebut, melampaui ekologi dapat diartikan sebagai sebuah upaya untuk melewati atau melebihi dari hubungan timbal balik antara makhluk hidup dan lingkungan sekitarnya.

\section{Pengolahan Air}

Secara definisi menurut $\mathrm{KBBI}$, pengolahan air berasal dari kata pengolahan yang bermakna proses, cara, perbuatan mengolah air. Dapat ditarik kesimpulan bahwa pengolahan air adalah proses perbuatan mengolah air menjadikan kondisi air tersebut lebih bersih atau menjadi dapat digunakan. Air bersih sendiri memiliki pengertian yaitu air yang digunakan untuk keperluan sehari-hari dan dapat diminum setelah dimasak (Permenkes RI No 416/Menkes/PER/IX/1990). Proses pengolahan air dapat meliputi beberapa unit seperti berikut: (Arifiani dan Mochtar Hadiwidodo, 2007)

a. Intake, proses pengambilan sumber air baik dari sungai, danau, maupun tanah.

b. Aerasi, proses penambahan oksigen terhadap air untuk menyisihkan gas terlarut.

c. Koagulasi, proses penambahan koagulan ke dalam air dan kemudian diaduk.

d. Flokulasi, proses pembentukan flok dan diaduk dengan udara.

e. Sedimentasi, proses pengendapan atau pemisahan partikel secara gravitasi.

f. Filtrasi, proses penyaringan air melalui media pasir atau filter sejenis.

g. Desinfektasi, proses membunuh bakteri patogen pada air baik dengan sinar UV ataupun dengan penambahan senyawa kimia.

h. Reservoir, proses penampungan air hasil olahan dan proses distribusi dengan pengaturan tekanan melalui katup dan pompa. 
Pengolahan air laut (Desalinasi Air Laut) memiliki prinsip mengurangi kadar garam berlebih dan kontaminasi dari air laut agar dapat digunakan kembali. Prosesnya dapat menggunakan 3 metode:

a. Vacuum Distillation, proses pemanasan air untuk menghasilkan uap air yang kemudian dikondensasi menghasilkan air yg dapat dimanfaatkan.

b. Reverse Osmosis, proses memanfaatkan tekanan untuk mendorong air melalui membran sehingga meninggalkan garam yang terkandung sebelumnya.

c. Multi Stage Flash, proses pemanfaatan penguapan air dengan tekanan rendah sehingga temperatur yang dibutuhkan lebih rendah dari distillation pada umumnya.

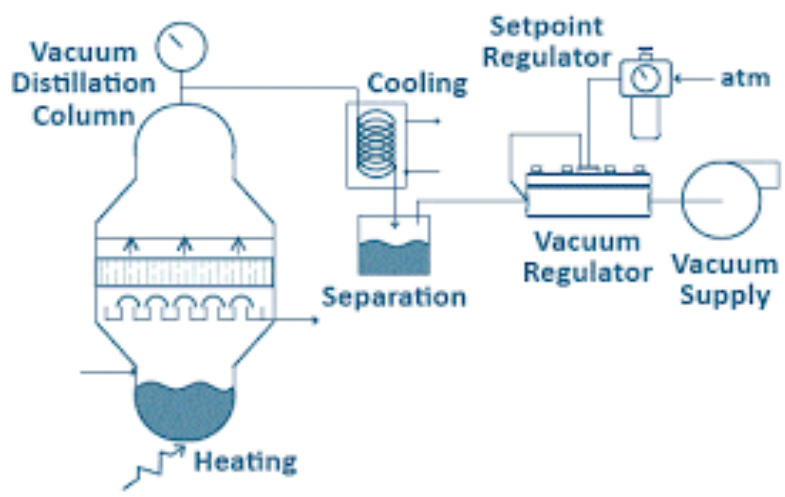

Gambar 1. Skema alur proses Vacuum Distillation Sumber:https://www.equilibar.com/application/vacuum-distillation

\section{Reverse Osmosis}

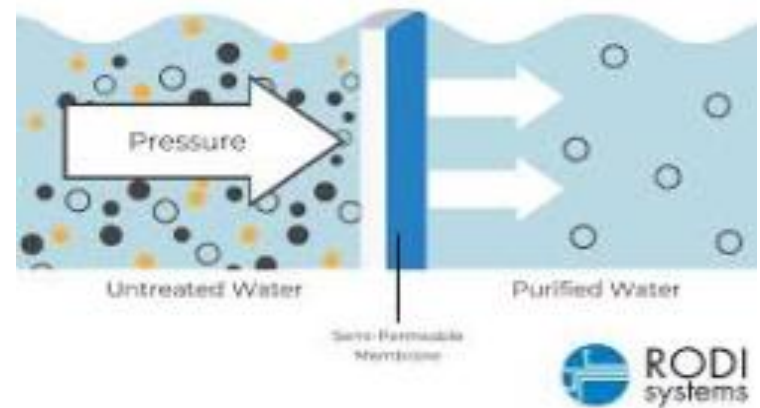

Gambar 2. Skema Proses Reverse Osmosis

Sumber:https://www.rodisystems.com/how-does-reverse-osmosis-work.html

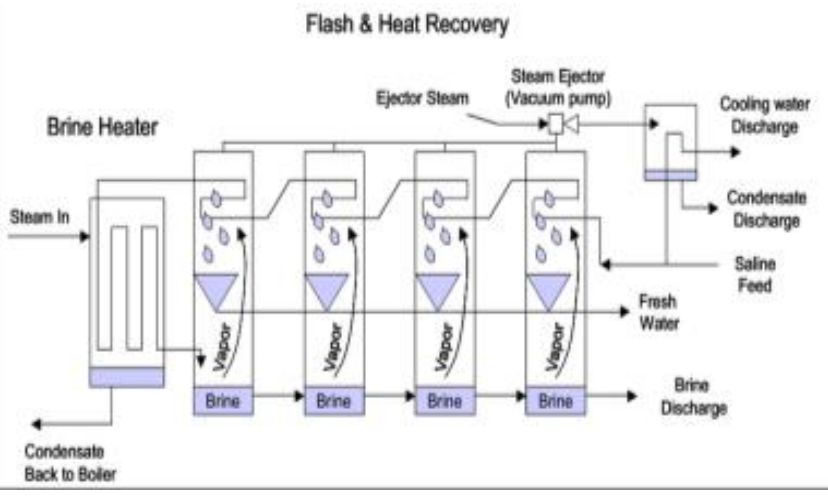

Gambar 3. Skema Alur Proses Multi Stage Flash

Sumber:https://www.researchgate.net/figure/The-Schematic-diagram-of-Multi-Stage-Flash-

Distillation-process-20-The-Fig-is-used_fig1_322370391 
Rain Water Harvesting adalah proses mencegat, menyampaikan dan menyimpan limpasan air hujan untuk penggunaan masa depan. Pemanenan air hujan untuk keperluan rumah tangga telah dipraktekkan di daerah pedesaan Ontario selama lebih dari satu abad. Tujuan dalam mengadaptasikan praktik ini pada daerah perkotaan untuk meningkat kegiatan konservasi air dan mengurangi limpasan air hujan. Ketika panen air hujan digunakan untuk mengairi area taman, terjadi evapotranspirasi oleh vegetasi atau menyalurkan air hujan ke dalam tanah, sehingga membantu untuk menjaga keseimbangan air (Dhalla dan Christine Zimmer, 2010).

Untuk pemanfaatan air hujan (rainwater harvesting) membutuhkan proses yang lebih sederhana dalam urutan sebagai berikut:

1. Penampungan, proses memanfaatkan media penyimpanan berupa waduk, kolam, maupun tangki untuk mengumpulkan air hujan.

2. Penyaringan, proses menyaring dedaunan atau benda-benda yang ikut terkumpul bersama dengan air hujan.

3. Pengolahan, air diproses lebih lanjut untuk mengurangi kontaminasi bakteri atau mikroorganisme yang terkandung.

\section{Landscape Urbanism}

Sejak muncul pertama kali pada pertengahan tahun 1990 oleh Peter Connolly dalam judul tesis master miliknya di Melbourne, landscape urbanism memiliki banyak definisi di banyak situasi, tetapi yang paling umum yaitu sebagai aliran postmodernist atau post-modernist dalam wujud respon terhadap New Urbanism dan transisinya menjauhi visi dan tuntutan dalam ruang lingkup arsitektur dan urban planning. Connolly dalam tesis masternya menggunakan istilah landscape urbanism sebagai sebuah kondisi hampir tidak adanya landscape urbanism saat ini dan dibutuhkannya sebuah artikulasi yang lebih baik karena kondisi eksisting sangat terbatas terhadap upaya eksplorasi terhadap lanskap.

Sedangkan menurut Tom Turner (1996), kota kota di masa depan akan memiliki berbagai macam lanskap yang tak terhingga, baik secara psikologi maupun secara fisik, baik di perkotaan maupun di pedesaan, berjalan bersama maupun terpisah. Mereka akan dipetakan dan direncanakan untuk tujuan khusus, dan disimpan sesuai dengan sistem informasi geografis (GIS), yang memiliki potensi untuk membangun dan mengembalikan rencana, gambar, dan catatan yang tak terhitung jumlahnya. Menurutnya Christopher Alexander tepat dengan mengatakan sebuah kota bukanlah sebatang pohon melainkan sebuah kesatuan lanskap.

Tom Turner juga merangkum 10 karakteristik Landscape Urbanism sebagai berikut:

a. Konteks yang luas, tidak terkekang dalam skala tertentu. Dapat diartikan dalam skala besar maupun kecil.

b. Sebuah konteks yang mencakup arsitektur dan teknik sipil.

c. Sebagai lengan mesin ketiga yang menghubungkan komponen-komponennya. (Mostafavi)

d. Dapat menyediakan kesempatan untuk meningkatkan interaksi sosial. (Talen)

e. Fungsi merupakan fokus utama dalam mesin Landscape Urbanism, tampilan bukan utama.

f. Menemukan potensi dan peluang dari lanskap.

g. Infrastruktur menjadi sorotan dalam proyek.

h. Mengembangkan hubungan antara alami dan sistem buatan.

i. Menghilangkan batasan antara lanskap dan kota sehingga menggabungkan keduanya menjadi kesatuan.

j. Jawaban kepada proyek yang kompleks atau memiliki fokus ekologi merupakan Landscape Urbanism. 


\section{Metode perhitungan intensitas hujan}

Metode Mononobe

Rumus perhitungan mononobe merupakan variasi dari rumus Sherman. Jika rumus-rumus intensitas hujan lainnya digunakan untuk menghitung Intensitas hujan dalam jangka pendek maka Mononobe merupakan rumus untuk menghitung Intensitas hujan setiap waktu berdasarkan data hujan harian.

$$
\mathrm{I}=\frac{R_{24}}{24}\left(\frac{24}{t}\right)^{2 / 3}
$$

Dimana:

$$
\begin{array}{ll}
\text { I } & \text { : Intensitas hujan }(\mathrm{mm} / \mathrm{jam}) \\
\mathrm{t} & \text { : lamanya hujan }(\mathrm{jam}) \\
\mathrm{R} 24 & \text { : curah hujan maksimum harian }(\mathrm{mm})
\end{array}
$$

\section{METODE}

\section{Site Visit}

Dengan keterbatasan akses di masa pandemi COVID-19, site visit hanya dilakukan satu kali dimulai dari transportasi publik terdekat dan memutari batasan site. Kondisi eksisting site adalah perumahan perkampungan dengan tinggi bangunan 1-2 lantai.

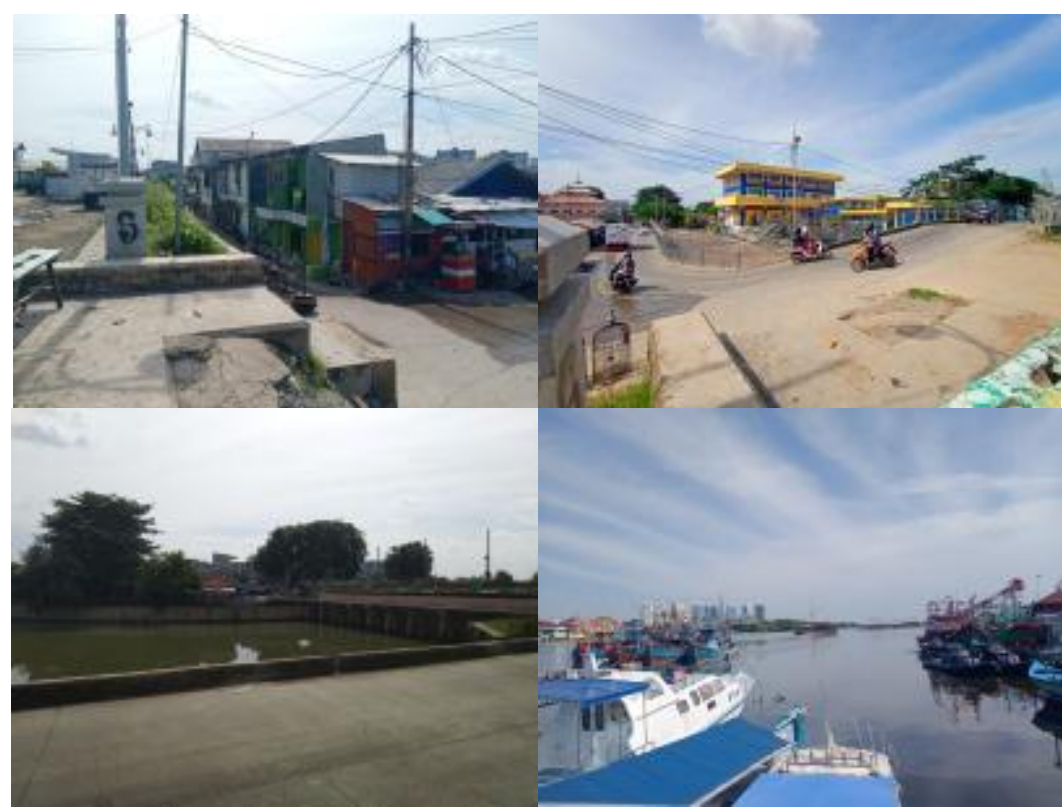

Gambar 4. Kondisi Eksisting Site

Sumber: Penulis, 2021

\section{Mapping}

Dengan menggunakan alat bantu peta digital dari google, cadmapper, dan snazzy map, maka dilakukan perhitungan jumlah hunian yang berada di dalam wilayah terdampak keterbatasan air bersih. 


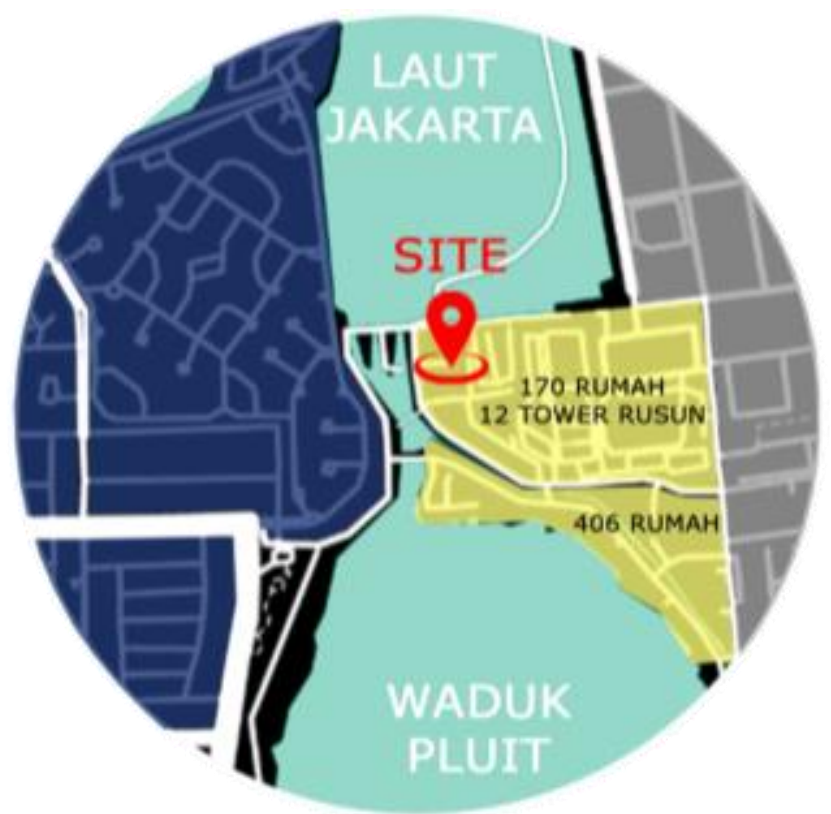

POTENSI PEMILIHAN SITE

- Terletak strategis di antara dua sumber

air yaitu Laut Jakarta dan Waduk

Pluit

Berada di dalam kawasan terdampak

masalah keterbatasan air bersih

\section{KETERANGAN}

Daerah hunian terdampak

keterbatasan air bersih

Daerah mayoritas industri

Daerah sudah terhubung PAM

Gambar 5. Gambar Mapping Area Terdampak

Sumber: Penulis, 2021

\section{Landscape Urbanism}

Dengan menggunakan prinsip karakteristik dari landscape urbanism, maka site terpilih dianalisis sebagai berikut.

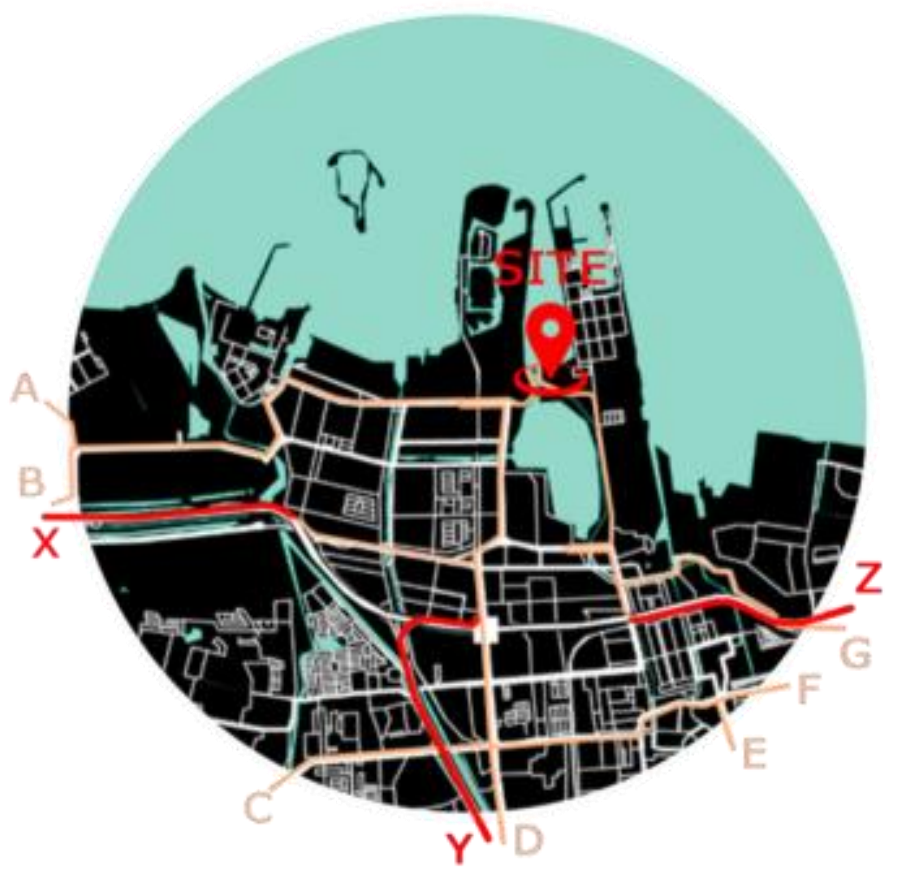

PENCAPAIAN MENUJU SITE DARI:

A Pantai Indah Kapuk (Pamai lanca)

B Kapuk/ Cengkareng

C Pesing/ Angke

D Grogolv Slipi

E Harmoni

F Mangga Dua

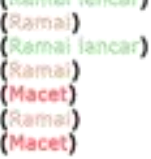

$x$ Tol Lingkar Barat/Bandara (Aamai lances)

Y Tol Dalam Kota(Semanggi)

2 Tol Dalam Kota (Priok)

Gambar 6. Gambar Analisis Akses Pencapaian Menuju Site

Sumber: Penulis, 2021 


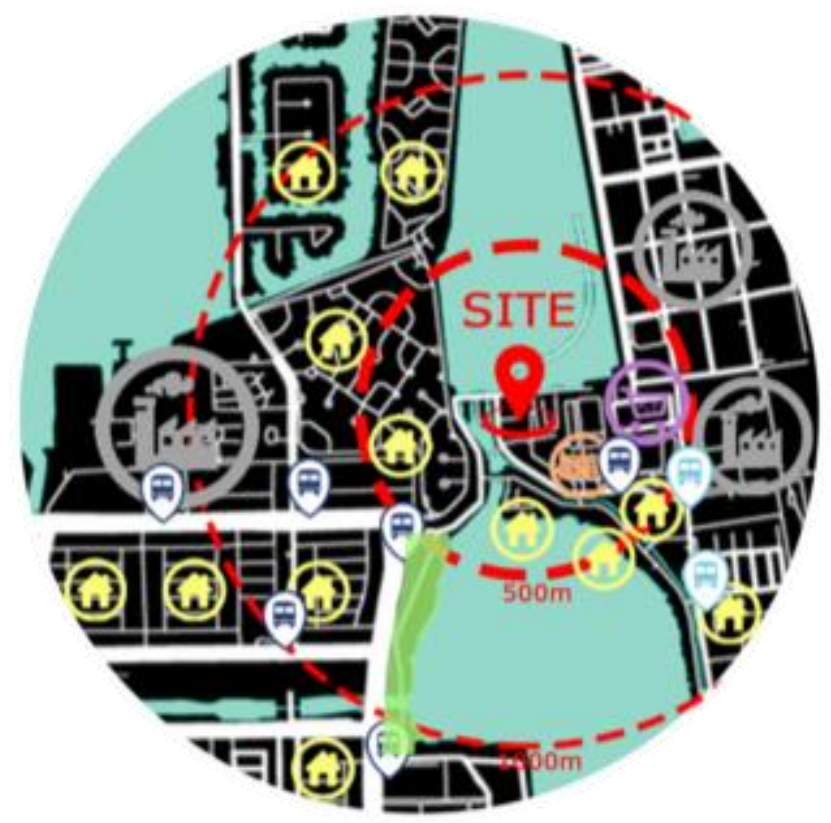

\section{LINGKUNGAN SITE \\ Hunian Tapak \\ Hunian Susun \\ Pasar Ikan \\ Industri \\ RPTRA Waduk Pluit}

AKSES TRANSPORTASI UMUM

EIA PIK-Balai Kota

Eif Rusun Waduk Pluit-

U11 Muara Baru-

Muara Baru:

Gambar 7. Gambar Analisis Konteks Lingkungan Site

Sumber: Penulis, 2021

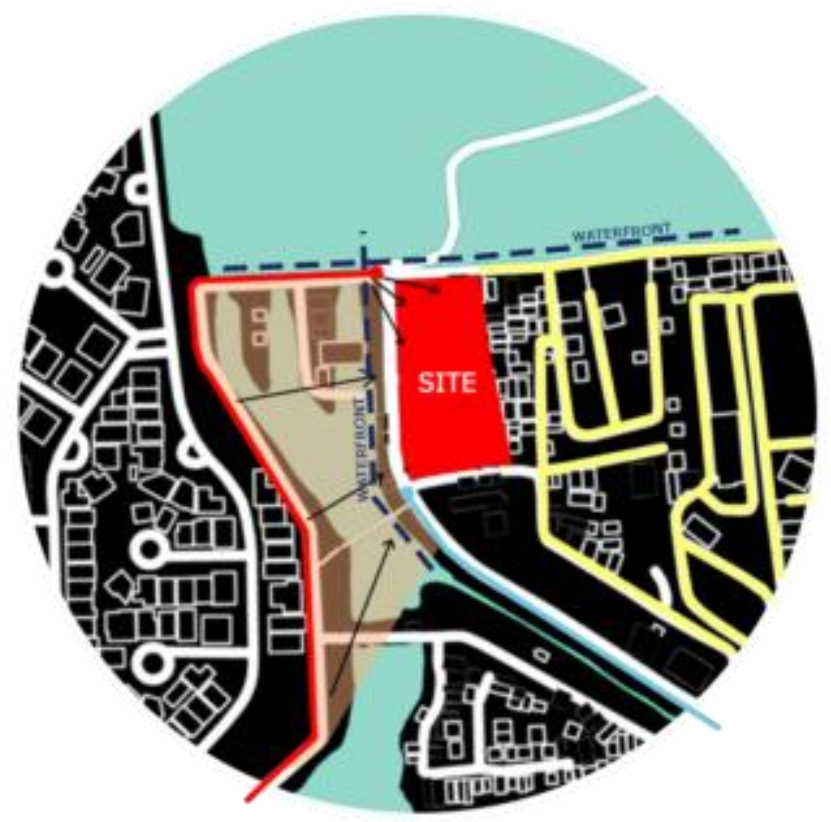

WAJAH TEPIAN AIR

Dengan lokasi strategis di tepi air, dan potensi visual o lingkungan sekitar maka sesuai untuk dikembangkan menjadi wajah Muara Baru dan kontribusi ruang publik tepian air. Pengembangan tampak bangunan terfokus terhadap sisi barat dan timur.

\section{KETERANGAN}

Dakses utama - Mayoritas melihat sisi barat dari site. Akses sekunder-Mayoritas melihat sisi selatan dari site Sisi timur lebih dilihat oleh. hunian 2 It dan rusun.

Gambar 8. Gambar Analisis Visualisasi Site dari Akses Pencapaian Utama Sumber: Penulis, 2021 


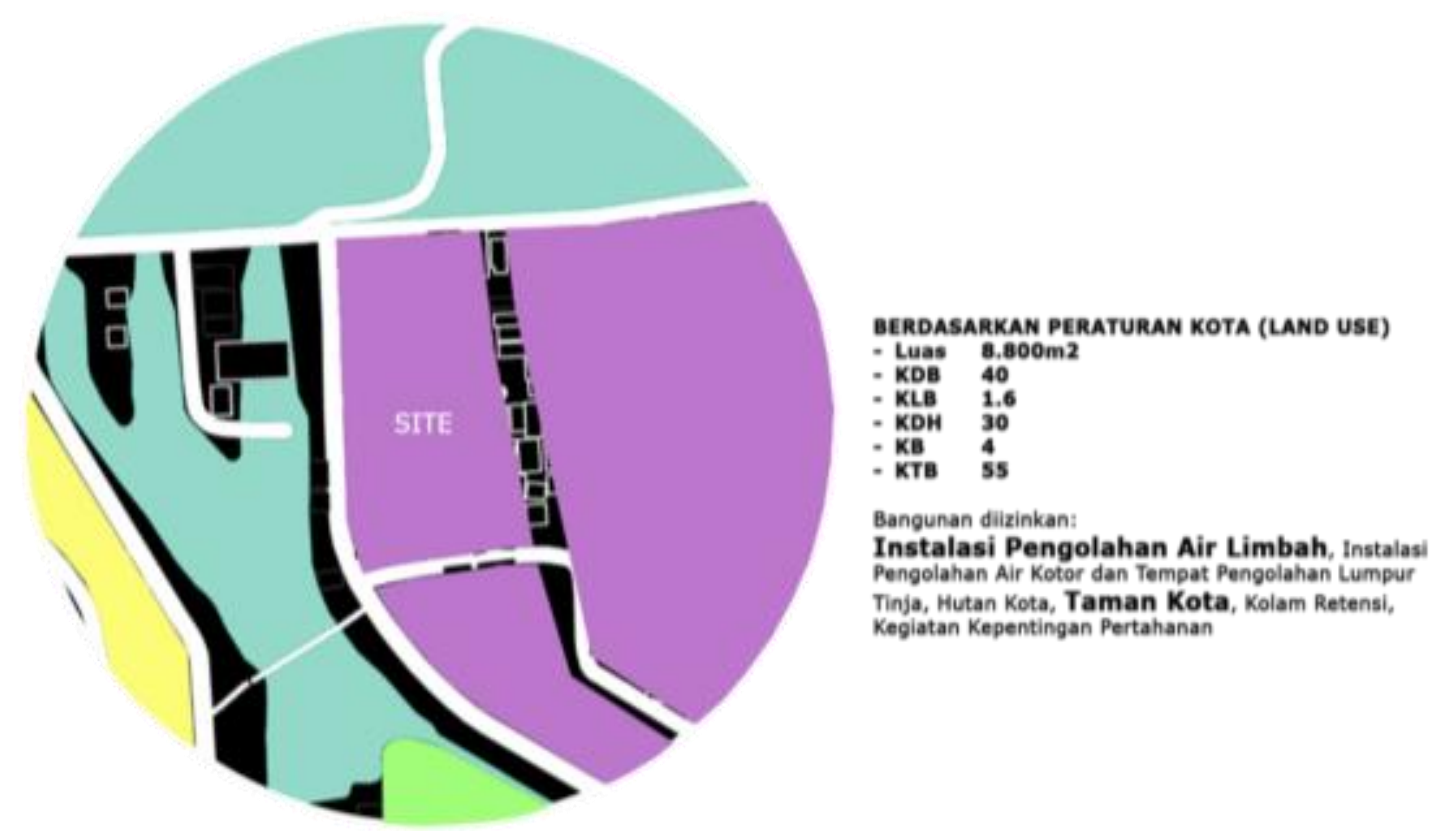

Gambar 9. Gambar Analisis Berdasarkan Peraturan Tata Guna Lahan Sumber: Penulis, 2021

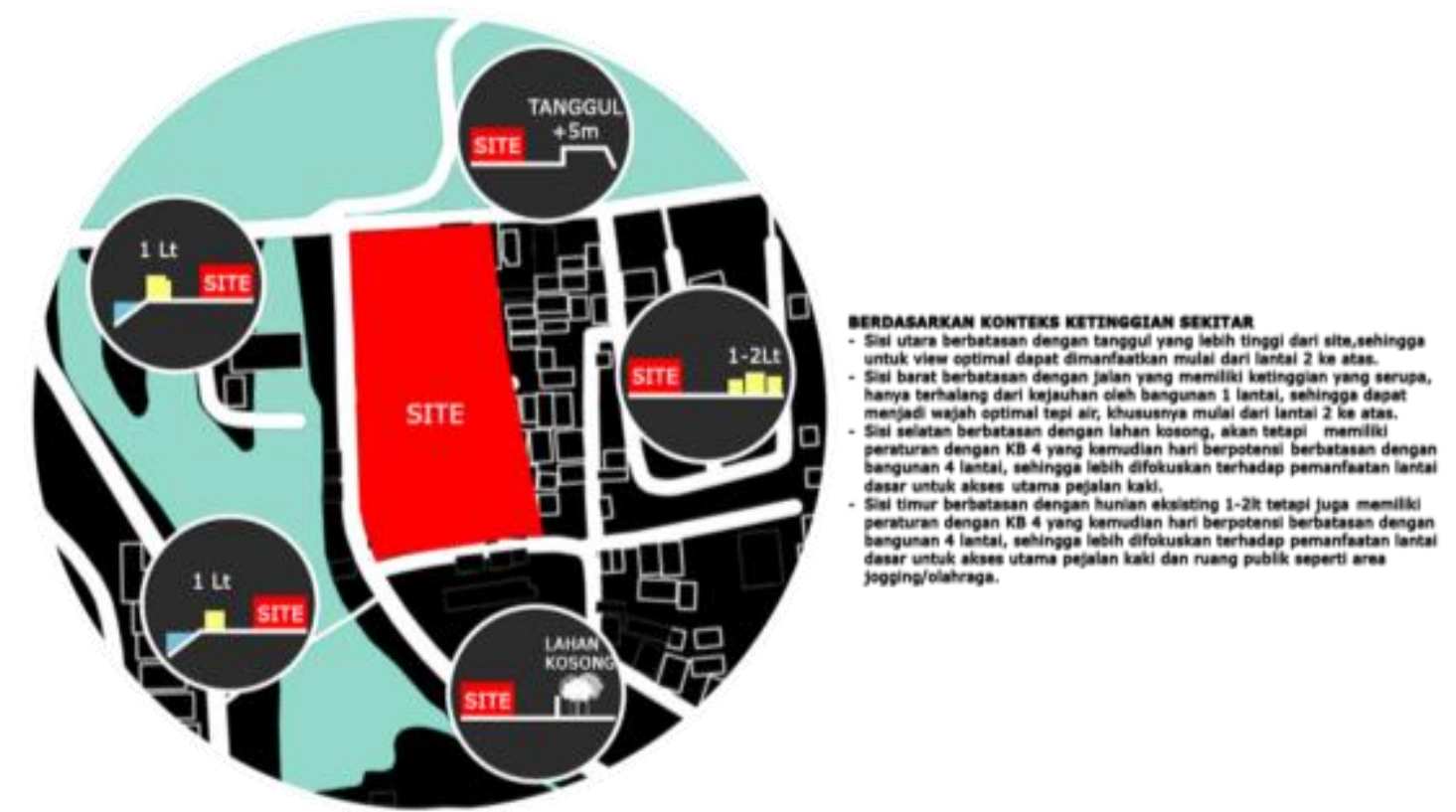

Gambar 10. Gambar Analisis Batasan Site Berdasarkan Fisik dan Kontur Sumber: Penulis, 2021

\section{Programming}

Dengan fungsi berupa bangunan pengolahan air dan fungsi penunjang rekreasi serta dipadukan dengan fungsi kios sebagai potensi dari lokasi, maka dirumuskan program sebagai berikut. Dimulai dari penentuan program-program dari fungsi terkait. Kemudian ditentukan ruangan-ruangan penting dan hubungan baik antara ruang dengan ruang maupun antara ruang dan zona. Penentuan akses dan sirkulasi dari program, serta keterbukaan terhadap jenis pengunjung baik dari pengunjung, staff, maupun pedagang. 


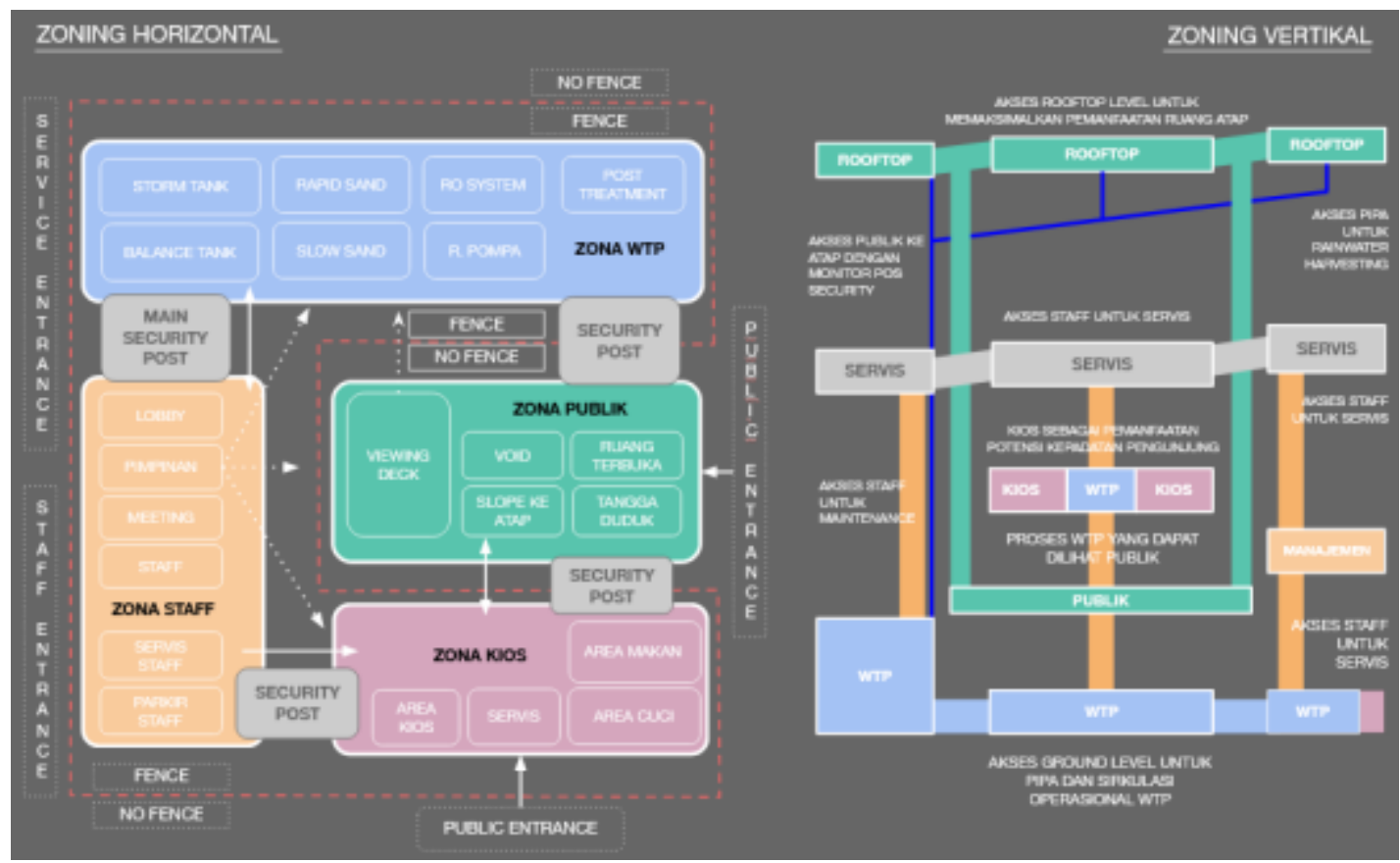

Gambar 11. Gambar Pembagian Zoning Program Secara Horizontal dan Vertikal Sumber: Dokumentasi Pribadi

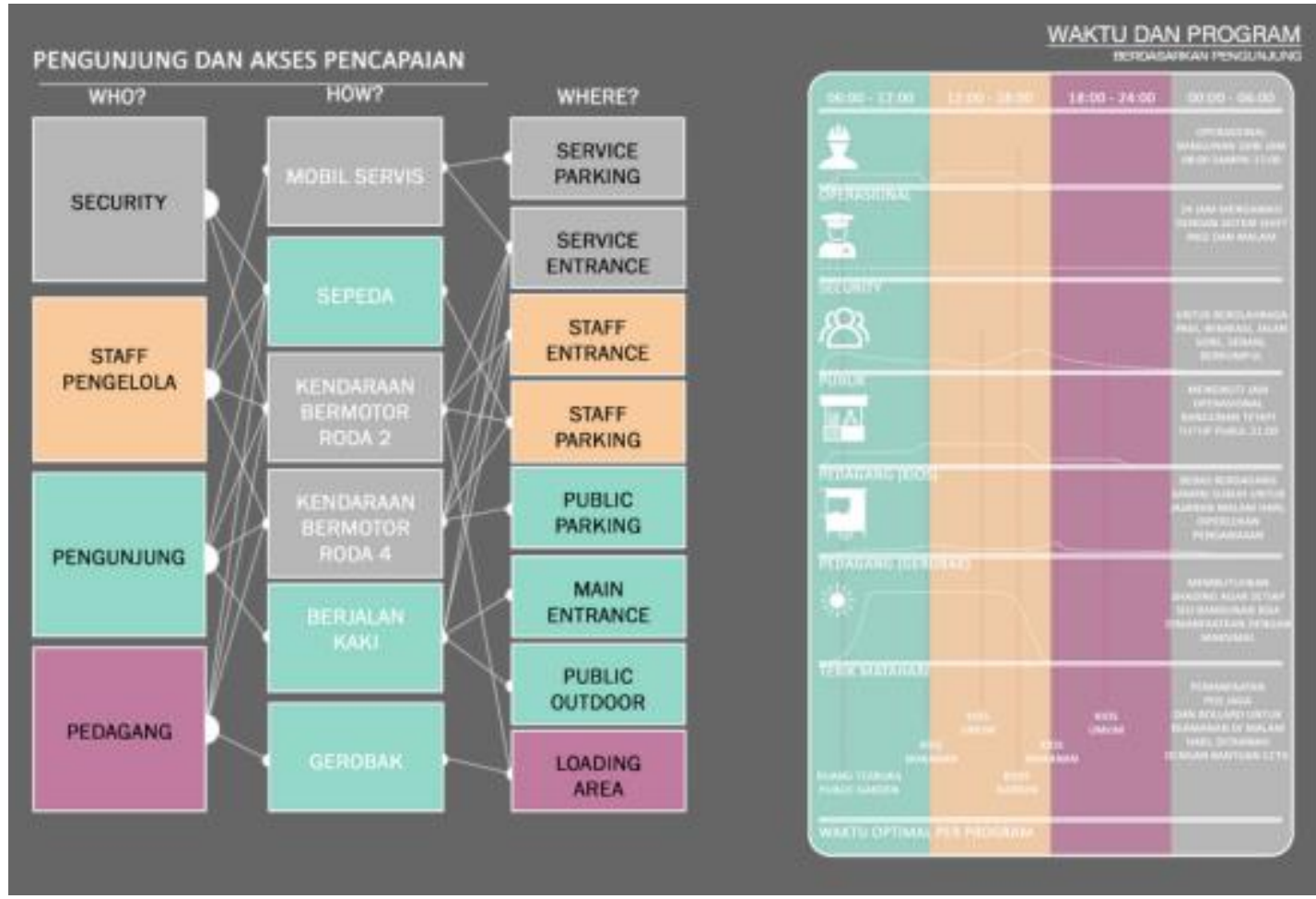

Gambar 12. Gambar Hubungan antara Akses, Jenis Pengunjung, dan Waktu Sumber: Penulis, 2021 


\section{DISKUSI DAN HASIL}

\section{Studi Gubahan Massa}

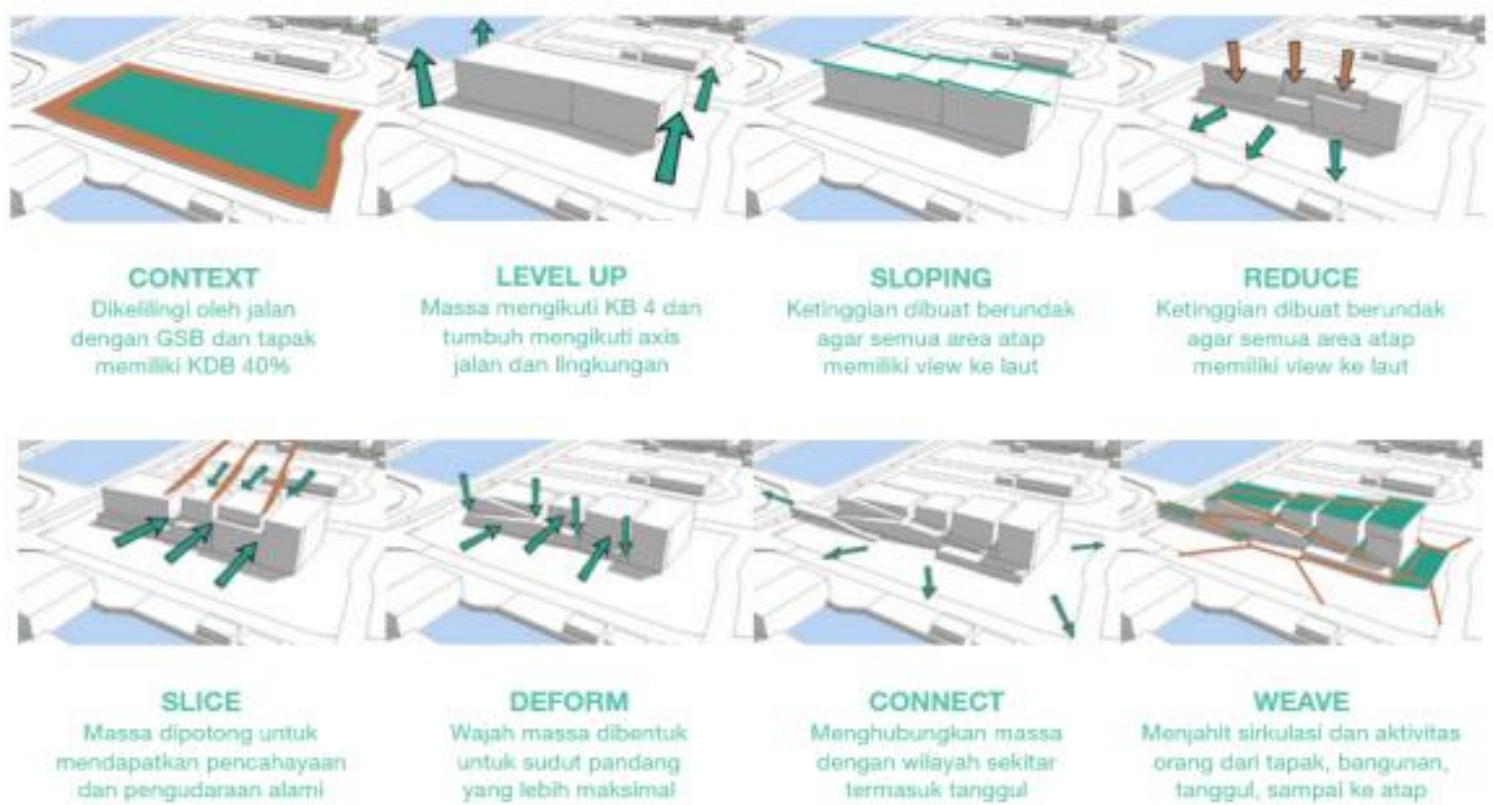

Gambar 13. Gambar Proses Studi Pengolahan Gubahan Massa Sumber: Penulis, 2021

\section{Usulan Desain}

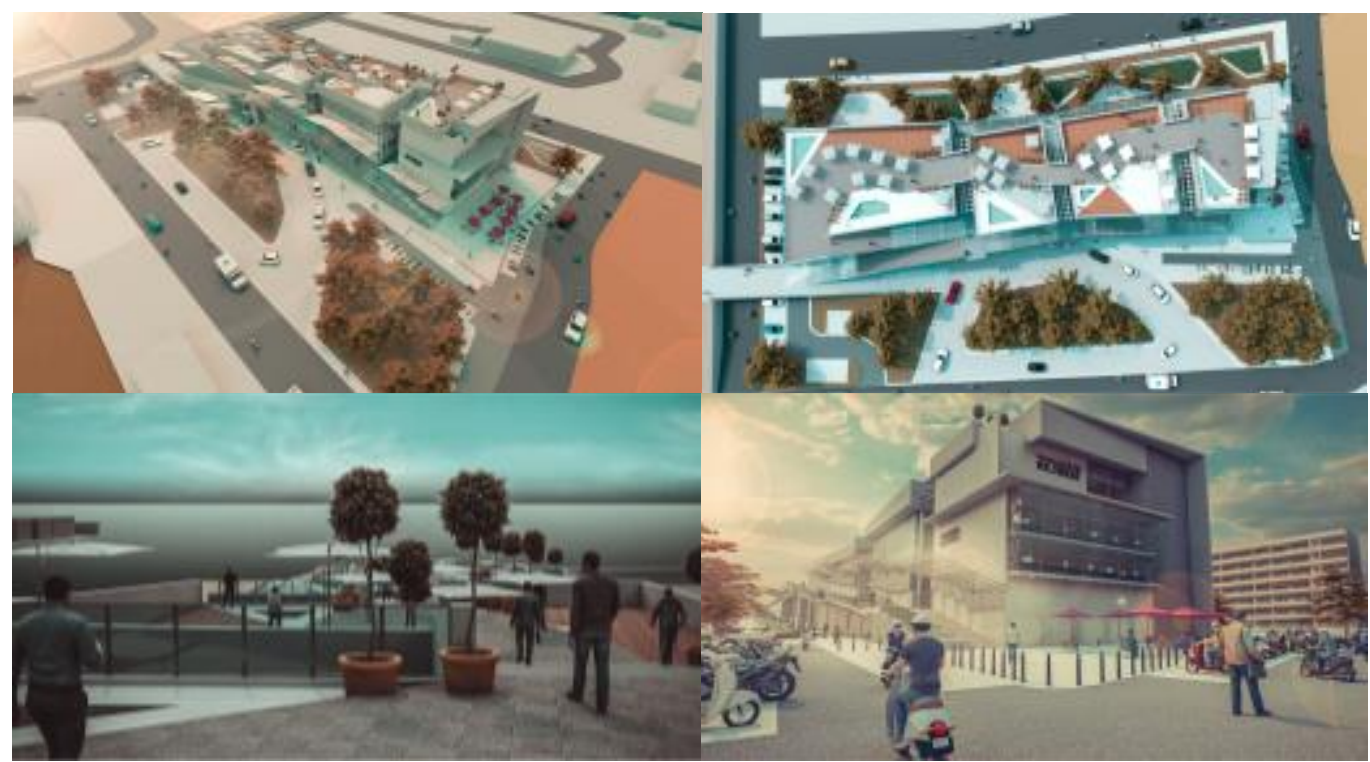

Gambar 14. Gambar Perspektif Visualisasi Proyek Pengolahan Air RE.TREAT Sumber: Penulis, 2021 


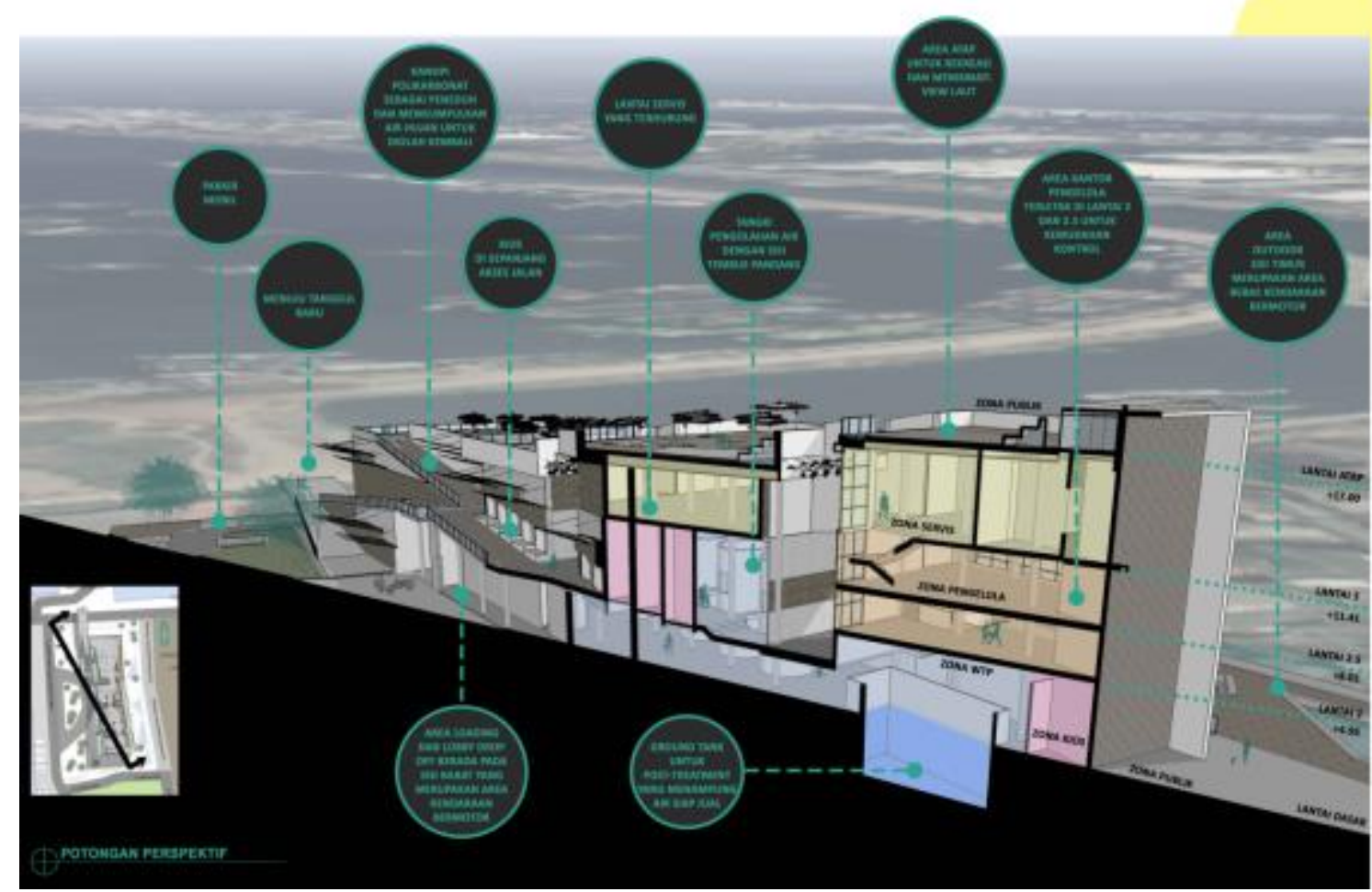

Gambar 15. Gambar Potongan Perspektif Pengolahan Air RE.TREAT

Sumber: Penulis, 2021

\section{Teknis Pengolahan Air}

Proyek Pengolahan Air RE.TREAT menerapkan proses pengolahan air yaitu perpaduan antara air hujan dan air laut dimana keduanya memerlukan proses yang berbeda seperti pada skema berikut.

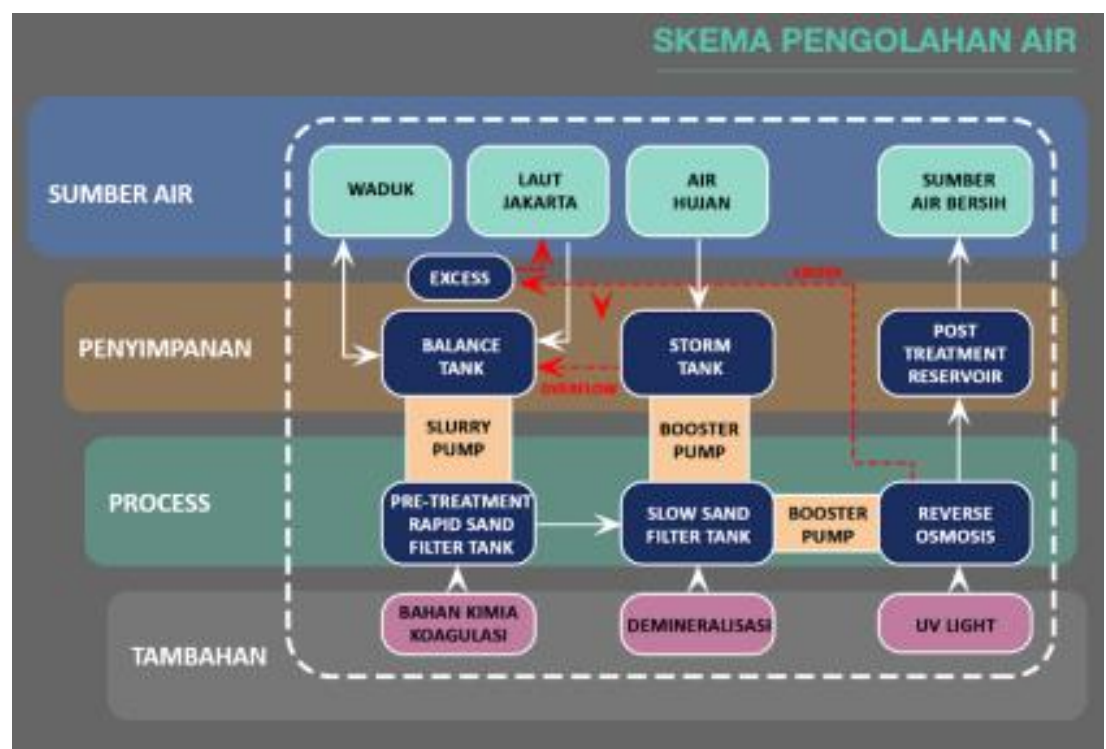

Gambar 16. Gambar Skema Urutan Pengolahan Air Sumber: Penulis, 2021

\section{Volume Air Hujan}

Sebagai kawasan yang terletak di daerah tropis basah, Muara Baru memiliki potensi curah hujan yang dapat dimanfaatkan ke dalam RWH (Rainwater Harvesting). 


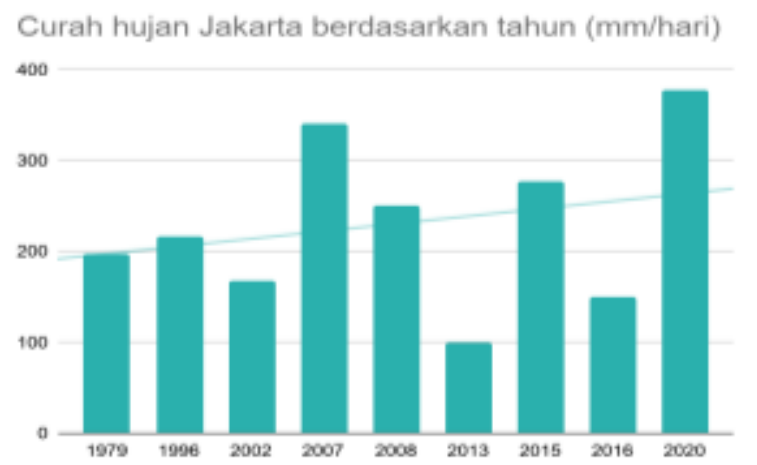

Gambar 17. Rata-rata Curah Hujan Jakarta per Tahun

Sumber: Rangkuman Pribadi dari Sumber Laman BMKG

Berdasarkan data curah hujan tahunan BMKG sebagai acuan, terlihat peningkatan rata-rata secara per tahun mulai dari $200 \mathrm{~mm} /$ hari di tahun 1979 dan fluktuatif menjadi $400 \mathrm{~mm} /$ hari di tahun 2020. Dengan merata-ratakan data yang dapat diakses, digunakan acuan rata-rata kumulatif curah hujan tahunan di angka $250 \mathrm{~mm} /$ hari.

Dengan menggunakan asumsi hujan rata-rata berada dalam intensitas 2 jam dari 24 jam dan menggunakan asumsi bahwa acuan rata-rata kumulatif curah hujan tahunan berada di angka $250 \mathrm{~mm} /$ hari, maka dapat dihitung intensitas hujan dengan rumus (Metode Mononobe) sebagai berikut:

$$
\begin{aligned}
& I=R 24 / 24(24 / \mathrm{t})^{2 / 3} \\
& I=250 / 24(24 / 2)^{2 / 3} \\
& I=10.42 \times 5.24 \\
& I=54.6 \mathrm{~mm} / \mathrm{jam}
\end{aligned}
$$$$
\begin{array}{ll}
\mathrm{R} 24 & =\text { curah hujan per hari }(\mathrm{mm} / \text { hari) } \\
\mathrm{t} & =\text { asumsi waktu intensitas hujan } \\
\text { (jam) } &
\end{array}
$$

Setelah didapat Intensitas hujan di atas, dapat dihitung juga volume air per hari dengan menggunakan metode rasional sebagai berikut:

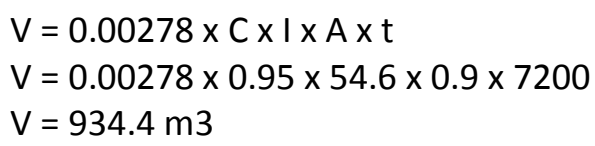

Berdasarkan hasil perhitungan tersebut maka potensi air hujan yang dapat dimanfaatkan kembali adalah sekitar $934 \mathrm{~m}^{3}$ (Referensi perhitungan: Rangkuti, et al. 2019)

\section{KESIMPULAN DAN SARAN \\ Kesimpulan}

Berdasarkan beberapa sumber yang menyatakan bahwa masalah keterbatasan air merupakan faktor teknis dan geografis, maka dapat disimpulkan untuk menyelesaikan masalah keterbatasan air dibutuhkan penyelesaian terhadap kedua faktor tersebut. Masalah geografis yang diangkat karena lokasi yang tidak dapat memanfaatkan air di sekitarnya seperti air tanah, air waduk, dan air laut, serta masalah teknis dimana daerah tersebut belum tersambung dengan pipa Perusahaan Air Minum. Oleh karena itu proyek Pengolahan Air RE.TREAT menjadi jawaban untuk mengolah air yang tersedia tetapi belum dapat diolah dan menjadikannya sumber air bersih bagi penduduk setempat dengan harga yang lebih terjangkau. Dengan demikian menjawab permasalahan teknis dan geografis di atas. Guna memaksimalkan fungsi lahan dan potensi lokasi, fungsi penunjang rekreasi dijadikan daya tarik untuk mendatangkan pengunjung sebagai visi interaktif dan ruang publik yang dapat dinikmati bersama. Hal ini menjadi upaya terobosan bahwa bangunan utilitas dapat dinikmati dan tidak hanya sekedar berupa bak / tangki yang tertutup secara konvensional. 


\section{Saran}

Dengan segala pembatasan dan protokol kesehatan di masa pandemi COVID-19, site visit dirasa kurang maksimal dan sebagian besar data yang didapat berasal dari media digital. Akan lebih baik apabila site visit dapat dilakukan lebih menyeluruh untuk dapat dilakukan pemetaan (mapping) yang lebih maksimal terkait kondisi lingkungan sekitar site.

Proyek Pengolahan Air RE.TREAT dapat dijadikan contoh referensi usulan desain untuk diterapkan di daerah lain dengan permasalahan yang serupa yaitu masalah keterbatasan air bersih. Berdasarkan proses mendesain, hal-hal penting yang perlu diperhatikan adalah daya tarik untuk mendatangkan pengunjung, dan kemampuan memanfaatkan potensi kepadatan pengunjung tersebut.

Dalam perancangan bangunan pengolahan air, aspek perawatan dan pembersihan dari sistem penyaringan maupun pemurnian air tidak kalah penting dengan sistem itu sendiri. Sehingga dapat disesuaikan dengan menggunakan alat bantu teknologi untuk memudahkan proses maintenance dari alat-alat pengolahan air tersebut.

\section{REFERENSI}

Arifiani, N F., Muchtar H. (2007). "EVALUASI DESAIN INSTALASI PENGOLAHAN AIR PDAM IBU KOTA KECAMATAN PRAMBANAN KABUPATEN KLATEN," Jurnal Presipitasi : Media Komunikasi dan Pengembangan Teknik Lingkungan, vol. 3, no. 2, pp. 78-85, Sep. 2007

Detiknews. (2019). Pak Anies, Warga Muara Baru Beli Air Bersih sampai Rp 50 Ribu Per Hari. Diunduh 22 Februari 2021 melalui,

(https://news.detik.com/berita/d-4637326/pak-anies-warga-muara-baru-beli-air-bersih-sampairp-50-ribu-per-hari)

Dhalla., C. Z. (2010). "Low Impact Development Stormwater Management Planning and Design". Ontario: Toronto and Region Conservation Authority and Credit Valley Conservation.

Haris, P. (2019). BPBD DKI Sebut Kawasan Muara Baru Kurang Air sebab Faktor Geografis. Diunduh 22 Februari 2021 melalui,

(https://tirto.id/bpbd-dki-sebut-kawasan-muara-baru-kurang-air-sebab-faktor-geografis-edXd)

Puspasari, R. Donny H. Dian C. (2018). "Studi Pemilihan Formulasi Empiris Perhitungan Intensitas Hujan yang Sesuai" Malang: Teknik Pengairan Universitas Brawijaya

Rangkuti, M. A. Anisah L. Rumilla H. (2019). "Evaluasi Drainase Di Jalan Haji Misbah Dan Jalan Multatuli Sekitar Sungai Deli Kecamatan Medan Maimun”. Sumatera Utara: Fakultas Teknik UISU

Safitri, R. U. (2020). Dengan judul laman "Bagaimana Proses dan Cara Kerja Desalinasi Air Laut?". Diunduh 22 Februari 2021 melalui, (https://adikatirtadaya.co.id/bagaimana-proses-dancara-kerja-desalinasi-air-laut//)

Turner, T. (2014). "Landscape design history \& theory: landscape architecture and garden design origins. "London: Gardenvisit.com 
